\title{
Effectiveness of Teaching Physical Education on Junior High School in Indonesia
}

\author{
Kristi Agust \\ ${ }^{1}$ Sekolah Pasca Sarjana \\ ${ }^{1}$ Universitas Pendidikan Indonesia, ${ }^{2}$ Universitas Riau \\ ${ }^{1}$ Bandung, ${ }^{2}$ Riau, ${ }^{1,2}$ Indonesia \\ kristi.agust@yahoo.com
}

\author{
Adang Suherman, Nuryadi Nuryadi \\ Fakultas Pendidikan Olahraga dan Kesehatan \\ Universitas Pendidikan Indonesia \\ Bandung, Indonesia \\ adangsuherman@gmail.com,nuryadi_71@upi.edu
}

\begin{abstract}
The purpose this study was to determine the effectiveness of amount of time spent by students in teaching Physical Education process. The method used in this research is descriptive with subjects consisted of 4 junior high schools in the city of Pekanbaru Indonesia consisting of 7 Physical Education teachers and 120 students. The number of samples consisted of 32 students taken by purposive sampling. This study used the Academic Learning Time-Physical Education (ALT-PE) instrument. The results showed that a lot of activities that students do during learning time, such as examples students active involved in learning, received the instruction, listen to rules and discussion with teachers, classroom management such as dividing groups and drinking breaks, switch from one task to another, wait their turn to do activities, and there are also those who are not involved in learning. Based on the results of the study, it was concluded that physical education learning was not effective, students must be actively involved in more than $50 \%$ of the total learning time.
\end{abstract}

Keywords-effectiveness; ALT-PE

\section{INTRODUCTION}

Physical education is education through physical activity in which a lot of learning about movement to support a person in living life argues that, "physical education is education through and about physical activity or in the native language is physical education is education and through movement" [1].

To find out how students can do this by using the ALT-PE (Academic Learning Time-Physical Education) instrument. This instrument is used to measure the amount of time in learning students involved in motor activity at an appropriate level of success [2]. In other terms, Instructional Time is to see the number of days in the school year, the number of hours in a school day, the exact time in minutes to summarize, and the amount of time a student is involved in learning [3].

Knowing students' academic learning time is a good way to evaluate learning. Learning is more useful if you have a better level of academic study time in physical and recreational physical education learning [4,5]. In physical and recreational physical education, increasing the time allocated to learning activities, choosing activities that are appropriate to the level of students and staying them are indicators of the efficient ones [6]. In addition, because this is an indicator to keep students interested and active in learning, ALT-PE is an important concept for teachers. The time provided for motoric activities in the lesson, and the time that students actually spend on this motor activity is a different concept $[7,8]$. That is why students spend time in class is an important problem in the learning process

Research on ALT-PE has been carried out by several previous researchers [2,9-12]. With the research revealing that the importance of student learning time as an indication of effectiveness in learning, those who want to find information about this research are to find out how physical and recreational physical education in adolescents in Indonesia. The hope is to provide insight into adding references to physical education teachers and to readers about how students spend time in the learning process of physical and recreational physical education.

\section{METHOD}

Subjects in this study were junior high schools in the city of Pekanbaru Indonesia which amounted to 4 schools consisting of 7 physical education teachers and 120 students. While the sample in this study was 32 students using purposive sampling technique. This study uses instruments and data analysis developed by Siedentop namely ALT-PE which serves to determine the time spent by students during learning [13].

\section{PROCEDURE}

A total of 4 junior high schools were chosen as research sites. The number of students involved was 120 male students but only 32 students were sampled. Data were obtained from the results of learning recordings for 7 physical education teachers in their respective classes. Recordings of learning are taken during I lesson hours (120 minutes) starting from the beginning to the end of physical education learning. After getting the results from the recording, data analysis was carried out using the ALT-PE instrument

\section{ANALYSIS DATA}

The second version of the ALT-PE instrument was used to measure the students' lesson involvement and the variation in lesson context accounted with the conditions. This was determined by examining the percentage time spent on each of the 35 student involvement The student involvement variables 
were interim, activity, management, transition, knowledge, waiting, and off-task,. The context variables were transition, management, warm up, technique, strategy, rules, skill practice, scrimmage, and game.

The group-time sample method was used with samples of the whole class in camera view being taken every 10 seconds throughout the lesson. Interobserver reliability for the ALT-PE coding results were $100 \%$ for the context variables and $92 \%$ for the student involvement variables.

\section{RESUlTS}

The results showed that, of the 32 samples coding, it was found that on average $28.84 \%$ of the learning time, active students were involved in learning, while $23.39 \%$ of the learning time was used to receive instruction, listen to the rules and discuss with the teacher. The rest is used for class management such as dividing groups, waiting for the next assignment from teachers, drinking breaks $22.10 \%$, waiting for their turn $16 \%$, and $9.61 \%$ of students not involved in learning.

\section{CONCLUSION}

The results showed that a lot of activities that students do during learning time, such as examples students active involved in learning, received the instruction, listen to rules and discussion with teachers, classroom management such as dividing groups and drinking breaks, switch from one task to another, wait their turn to do activities, and there are also those who are not involved in learning. Based on the results of the study, it was concluded that physical education learning was not effective, which states that students must be actively involved in more than $50 \%$ of the total learning time (1).

Regarding the results of the study, it is suggested that Physical Education teachers must use methods / styles in learning that are more suitable for improving the quality of learning no longer using traditional methods / styles. Reducing the time allocated for class management, the transition between providing knowledge and practice, and reducing student waiting time in moving according to the material. Waiting period in the Physical Education courses could sometimes cover the half of the course, and concluded that this period could be shorten with the chosen activities and games. Within the findings of this study, the very teaching style can be said among the factors that shortens the waiting period [14].

The findings of this study provide insight into many aspects of physical education programs. It is encouraging that physical education programs are being given consideration for daily student participation; how- ever, teachers must continue to strive for quality physical education programs [15].

A quality program depends partially on teachers setting appropriate class contexts and then monitoring student involvement. The challenge to physical educators should be to set a favourable context for learning and then ensure that students remain on-task and successfully engaged with the subject matter.

For further study, this study suggests doing in a larger class group, also in class groups that use other physical education learning methods / styles so that they can compare teaching methods / styles which are more effective in improving student academic learning time.

\section{REFERENCES}

[1] A. Suherman, Revitalisasi Pengajaran dalam Pendidikan Jasmani. Bandung: CV Bintang Warli Artik, 2009.

[2] S. Silverman, R. Devillier, and T. Ramirez, "The validity of academic learning time-physical education (ALT-PE) as a process measure of achievement," Res Q Exerc Sport, vol. 62, no. 3, pp. 319-325, 1991.

[3] A.M. Lee and C. Poto, Instructional Time Research in Physical Education: Contributions and Current Issues, pp. 63-73, 2012.

[4] D. Siedentop, Developing Teaching Skills in Physical Education. Daryl Siedentop, Deborah Tannehill. Mountain View. Calif. : Mayfield Pub., 2000

[5] D. Siedentop, "Academic Learning Time: Reflections and prospects," Journal of Teaching in Physical Education, Dodds \& Rife (eds., Monograph, pp. 3-7, 1983.

[6] D. Siedentop, Developing Teaching Skills in Physical Education (3rd ed). Mayfield Publishing Company: CA 94041, 1991.

[7] A. Yıldırım and S. Çiçek, Öğretmenlik Uygulaması Yapan Aday Beden Eğitimi Öğretmenlerinin Derslerindeki Akademik Öğrenme Süreleri, Uluslararası Spor Bilimleri Kongresi, 27 - 29 Ekim, Antalya, 2002.

[8] J.M. Harrison and C.L. ve Blakemore, Instructional Strategies for Secondary School Physical Education (3rd Ed.). Dubuque: Wm. C. Brown Pub, 1992

[9] P. Godbout, J. Brunelle, and M. Tousignant, "Academic learning time in elementary and secondary physical education classes," Res Q Exerc Sport, vol. 54, no. 1, pp. 11-19, 1983.

[10] D.J. Leach and K.L. Ingram, "Educational Psychology: An International," Journal of The Effects of Information and Feedback on Teachers' Classroom Behaviour and Students' Academic Engaged Time, pp. 37-41, 1983.

[11] L. Beauchamp, P.W. Darst, and L.P. Thompson, "Academic Learning Time as an Indication of Quality High School Physical Education," J Phys Educ Recreat Danc, vol. 61, no. 1, pp. 92-95, 1990.

[12] P.A. Hastie and J.E. Saunders, "Effects of class size and equipment availability on student involvement in physical education," J Exp Educ., vol. 59, no. 3, pp. 212-224, 1991.

[13] D. Siedentop, M. Tousignant, and M. Parker, Academic Learning TimePhysical Education: Coding manual (2nd ed.). Columbus, OH: Ohio State University, 1982.

[14] T. Templin, "Triangulating ALT-PE: A Research Consideration," Journal of Teaching in Physical Education, Monograph, Dodds \& Rife (eds.), pp. 38-41, 1983.

[15] L. Beauchamp, P.W. Darst, and L.P. Thompson, "Academic Learning Time as an Indication of Quality High School Physical Education," J Phys Educ Recreat Danc, vol. 61, no. 1, pp. 92-95, 1990. 